ELORE (ISSN 1456-3010), vol. 16 - 2/2009.

Julkaisija: Suomen Kansantietouden Tutkijain Seura ry.

[http://www.elore.fi/arkisto/2_09/pk_fingeroos_2_09.pdf]

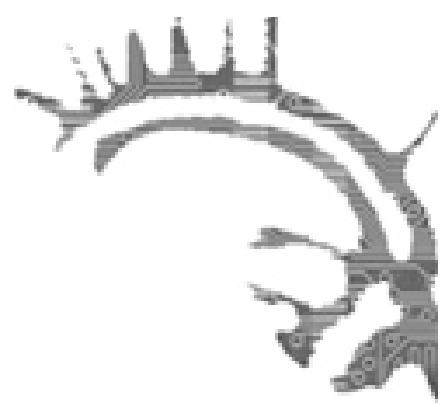

\title{
PäÄKIRJOItus
}

\section{Huojentunein MiElin}

\section{Outi Fingerroos}

Sinikka Vakimo kirjoitti Eloren 2/2004 pääkirjoituksensa alussa, että "nyt julkaistava Elore on viimeinen, johon kirjoitan päätoimittajana". Nyt, vuoden 2009 lopussa, ihmettelen väistyvänä päätoimittajana, miten nopeasti viisi vuotta on mennytkään. Samalla tunnen oloni tyytyväiseksi ja helpottuneeksi, sillä Elorella on osaava toimituskunta ja lehteä toimitetaan melkoisella pieteetillä. Huojentunut olen ennen kaikkea siksi, että lehdellemme löytyi pätevä ja innokas päätoimittaja jo kuluneena vuotena. Filosofian tohtori Petja Aarnipuu on vuoden 2009 häärinyt rinnallani toisena päätoimittajana ja on näin saanut eväät jatkolle etukäteen. Päätoimittajuus siirtyy Petjan myötä Jyväskylästä Helsinkin - mikä sopii Eloren filosofiaan erinomaisesti, olemmehan nykyisin kaikki alamme yliopistoyksiköt kattava toimija niin kirjoittaja- kuin toimittajakuntammekin puolesta.

\section{MuistelukerrontaA}

Omalla kaudellani Eloressa on tapahtunut paljon, ja monesti päätoimittajan työ on vienyt kaiken ajan omalta tutkimukselta iltasella. Jossain vaiheessa matkaani päätin, että Elore olkoon oma harrastukseni, jätin ylimääräiset jumpat, maraton-treenit ja rullaluistelut. Muutama vuosirengas tästä nojatuoliharrastuksesta on toki kertynyt, mutta olen sitä mieltä, että Eloren päätoimittaminen on ollut paljon mukavampaa hommaa kuin pitkän matkan juokseminen räntäsateessa. En siis kokonaan jätä Elorea, mutta siirryn vankasti takarivin toimittajaksi. Elore säilyy raikkaana ja innovatiivisena lehtenä vain tätä tietä: tarvitsemme uusia vastuunkantajia ja ideoijia.

Paras hetki päätoimittajakaudeltani on ehdottomasti alkuvuosi 2006, jolloin Suomen Kansantietouden Tutkijain Seuran (jatkossa SKTS) silloinen esimies Tarja Kupiainen soitti ja ilmoitti suuren ihmeen: Elore on päässyt valtiontuelle! Henkselimme paukkuivat silloin kovin - itse palasin asiaan monessa pääkirjoituksessa. Pidempään Eloren vapaan saatavuuden verkkojulkaiseminen ei olisi voinut jatkua, sillä talkootyö ilman vakituista toimitussihteeriä oli vuonna 2005 tiensä päässä ja toimituskunta 
takki tyhjänä. Suunnittelimme jopa paperilehdeksi siirtymistä, sillä se tuntui ainoalta tieltä eteenpäin. Oljenkortemme oli opetusministerin julkaisema Avoimen tieteellisen julkaisutoiminnan työryhmän muistio (2005:8), jossa Elore mainittiin yhtenä ensimmäisistä täysin avoimeen saatavuuteen perustuvista tiedejulkaisuista.

Itse muistan myös vuoden 2007, jolloin pohdimme, rohkeneeko Elore muuttaa Joensuun yliopiston cc.joensuu.fi -palvelimelta Tieteellisten seurain valtuuskunnan palvelimelle. Paikattomuuden pelko oli silloin konkreettinen, mutta näin jälkeenpäin ajatellen tie oli jo valmiiksi meitä varten viitoitettu, onhan TSV merkittävä tieteellisten seurojen tukija. Kaiken lisäksi olisimme ilman muuttoa jääneet internetin topografiassa näkymättömiin. SKTS rekisteröi muuton yhteydessä oman elore.fi-verkkotunnuksen ja otti käyttöön osoitteen <www.elore.fi>. Kotisivutkin uudistettiin samassa rytäkässä.

Turha seikkailu sen sijaan oli verkkojulkaisujärjestelmä OJS - Open Journal Systems. Siirryimme sen koekäyttäjäksi osana TSV:n julkaisupalveluyksikön käynnistämää hanketta vuonna 2007. OJS osoittautui erittäin hankalaksi järjestelmäksi, toimitustyössä se oli kokemuksemme perusteella turha. Vankka mielipiteeni onkin, että verkkolehti on helpoin toimittaa perinteisin keinoin eli suoraan kirjoittajien kanssa kommunikoimalla. Tunnuksia, salasanoja, käyttöohjeita, ylläpitovelvollisuuksia ja kirjautumisongelmia on aivan tarpeeksi ilman OJS-järjestelmääkin.

\section{ELOREN NUMERO 2/2009}

Eloren syysnumero on runsas. Lehden alussa on kaksi oppihistoriallisesti kiinnostavaa tekstiä: loppuvuodesta 2004 eläkkeelle jääneen professorin Bo Lönnqvistin ja vuoden 2009 alussa seuraajanaan aloittaneen Hanna Snellmanin haastattelut, jotka on kirjoittanut etnologian amanuenssi Elina Salminen. Artikkelitoimituksella puhdetta on syksyllä ollut kahdeksan tekstin verran. Referoituja artikkeleita mukana on kaksi, teemoina ovat Vellamo-merenneidon kansallisen kuvittelun tavat ja lähiökenttätyön haasteet Italiassa. Katsausartikkeleita ja katsauksia on mukana peräti kuusi. Teemat seurailevat mielenkiintoisesti perinteentutkimuksessa ja lähialoilla käytyjä keskustelua. Särmääkin teksteistä on löydettävissä.

Ajankohtaisia tekstejä mukana on poikkeuksellisen paljon. Mukana on muiden muassa kaksi lektiota, tuoreen Kulttuurintutkimuksen seuran esittely ja mielenkiintoisia seminaariraportteja. Ajankohtaista-palsta onkin miellyttävä tapa ottaa siivet selkään ja lähteä nojatuolimatkalle maailmalle. Kirja-arviot täydentävät miellyttävän matkailun mahdollisuuksia, sillä 17 kirja-arviota on mieletön kurkistus kulttuurien tutkimuksen julkaisumaailmaan.

Lehtemme toimittajat, kirjoittajat ja tuntemattomaksi jävät asiantuntija-arvioijat ovat jälleen ahertaneet tekstien parissa vaivojansa säs̈stelemättä. Päätoimittajana lausun nöyrän kiitokseni Teille kaikille. Pidetään Elore elinvoimaisena jatkossakin!

Dosentti Outi Fingerroos työskentelee etnologian yliassistenttina Jyväskylän yliopistossa ja koordinoi Monikulttuurisuus ja vuorovaikutus -osaamiskeskusta. 